ELORE (ISSN 1456-3010), vol. 19 - 2/2012.

Julkaisija: Suomen Kansantietouden Tutkijain Seura ry.

[http://www.elore.fi/arkisto/2_12/aberg.pdf]

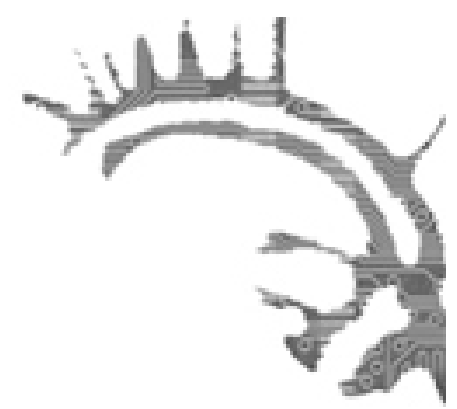

KirJa-ARViO

\title{
ROMANIHISTORIAA KULTTUURIN SISÄISTÄ NÄKÖKULMAA KUNNIOITTAMALLA
}

PULMA, PANU (toim.) 2012: Suomen romanien historia. Helsinki: SKS. 494 sivua.

\section{Kai Åberg}

Viimeaikaisen eri kansallisiin vähemmistöihin kohdistuneen etnopoliittisen liikehdinnän ja kehityksen seurauksena myös romanikulttuuria lähestyvät tutkimukset ja muut julkaisut ovat huomattavan kiinnostuksen kohteina kaikkialla Euroopassa ja muualla maailmassa. Lukuisten maiden romaneista on julkaistu viime vuosina suuri määrä kansainvälisiä tutkimuksia, raportteja, artikkeleita, äänitteitä ja videojulkaisuja. Suomen romanien kulttuurista ei ole ollut kuitenkaan saatavilla kovinkaan montaa kokonaisesitystä. Suomen romanien historia täyttää tyhjiötä historian näkökulmista.

Panu Pulman toimittama Suomen romanien historia on jaettu kolmeen kaikkiaan kuudestatoista artikkelista koostuvaan osioon, joista ensimmäinen keskittyy varhaiseen romanihistoriaan (1500-luvulta toiseen maailmansotaan). Toinen osio, "Kohti täyttä kansalaisuutta - 1940-luvulta 2000-luvulle", käsittelee romanien aseman yhteiskunnallista muutosta, etnopolitiikan kansallisia ja kansainvälisiä yhteyksiä sekä Mustalaisyhdistyksen ja Mustalaislähetyksen syntyä. Kolmas jakso, "Kielen ja kulttuurin muutos", nostaa esiin romanikielen, musiikin ja kulttuurin keskeiset piirteet näiden muutoksia unohtamatta.

Kattavuudessaan Suomen romanien historia on merkittävä kokoelma romanihistoriaa, etnopolitiikkaa, romanikieltä ja -kulttuuria muutoksineen lähestyvä teos. Kirjoittajina 
on joukko maamme johtavia romanihistorian tutkijoita, jotka artikkeleissaan hyödyntävät lähdeaineistoina pääasiassa arkistomateriaalia. Tekijät ovat pyrkineet nostamaan elämäkerrat (esimerkiksi Miranda Vuolasrannan, Rainer Frimanin, Aale Lindgrenin ja Saska Borgin), haastattelupoiminnat ja valokuvat entistä tärkeämmiksi lähderyhmiksi ja tuottaneet tällä tavalla arjen historiaksi, mikrohistoriaksi ja uudenlaiseksi henkilöhistoriaksi kutsuttavaa tutkimusta. Näin perinteisesti naisille tyypillisenä pidetty tapa kirjoittaa historiasta elämäkerrallisesti henkilöhistorian kautta on rantautunut (tai pyrkii rantautumaan) myös miehiselle historiankirjoituksen mantereelle. Toisaalta tämänkin teoksen valossa näyttää siltä, että menneisyys on vahvasti maskuliininen saareke niin tapahtumien kuin tulkintojenkin valossa. Yleistäen voisi sanoa, että mitä kauempana ajallisesti liikehditään, sitä miehisemmäksi menneisyys värittyy.

\section{KULTTUURIN SISÄISEN JA ULKOISEN NÄKÖKULMAN DILEMMA?}

Tekijät toivovat, että romaniväestön historian tutkiminen ja kirjoittaminen olisi jatkossa enenevässä määrin romanien oma haaste ja päämäärä. Tavoite on ajanmukainen, sillä henkilökohtaisia aineistoja on 2000-luvun suomalaisessa historiantutkimuksessa käytetty etenkin kulttuurihistoriallisissa tutkimuksissa. Näissä näkökulman painopiste on siirtynyt arjen ja kulttuurin tarkasteluun. Henkilökohtaisuus pyrkii olemaan teoksen yhteinen nimittäjä, mutta toisaalta sitä muovaavat monet seikat, esimerkiksi politiikan ja henkilökohtaisten suhteiden sekoittuminen, romanikulttuurin kollektiivisuus ja yksilöllinen orientaatio sekä eri tavoin rajoitetut romanielämän olosuhteet. Silti tutkimus pyrkii tuomaan romaninäkökulman mukaan historiakeskusteluun sitaattien, haastattelupoimintojen, valokuvien ja folkloreaineksen avulla. Kirjan takakannen teksti, "Perusteos Suomen romaniväestön vaiheista tuo vahvasti esiin romanien oman näkökulman historiaansa", antaa odottaa paljon. Silti paikoin lukijan vaikutelmaksi jää jo kertaalleen kirjoitetun historian toisto näennäisesti kulttuurin sisäistä perspektiiviä korostaen.

Suomen romanien historia on varsin omaleimainen, ja sitä tuleekin tarkastella lähemmin. Teoksessa saamme samalla tietoa romanien kansallisista joukkosymboleista, jotka ehkäisevät avoimen joukon syntymistä. Kannattanee siis aluksi katsoa romanihistoriaa joukon näkökulmasta. Romanien menneisyydestä löytyy kyllä paljon joukkokokemuksia - sosiaalista diskriminaatiota, assimilaatiopolitiikkaa ja suoranaista vainoa - jotka ovat voittopuolisesti liittyneet tuskallisiin ja kielteisiin tapahtumiin. Menneisyys on läsnä nykyhetkessä paitsi kertomusten myös artefaktien kautta. Menneisyydessä syntyneet kulttuurituotteet kertovat lukijalle menneestä ja muodostuvat muistiksi. Sellaisten etnisesti ladattujen käyttöesineiden ja tarvikkeiden kuin hevosten ja kärryjen, naisten ja miesten korujen kuvittaminen ja esiin nostaminen luo lisämerkityksiä historiankirjoitukselle lataamalla mielikuvia varhaisemmasta ja osin nykyisestä romanielämästä. Onkin totta, että menneisyyden jäsentäminen kanavoituu monenlaisiin kulttuurituotteisiin, esimerkiksi valokuviin, käsitöihin ja lauluihin, ja sen tähden on luontevaa ajatella, että menneisyyttä analysoidaan näiden kautta. Viime vuosina etenkin romanimusiikkia käsittelevät dokumentit toimivat hyvänä osoituksena suuntauksesta. Tämä nykyhetkeen 
Kai Åberg: Romanihistoriaa kulttuurin sisäistä näkökulmaa kunnioittamalla

säilyneiden menneisyyden artefaktien muodostama muisti voi olla kuitenkin hyvin valikoiva. Muistin valikoivuus tulee ymmärretyksi toimijoidensa kautta ja syystäkin esimerkiksi uskonnollisten liikkeiden merkitys Suomen romanien historiassa korostuu.

Kun luen teosta Suomen romanien historia, taustallani kolkuttaa vanha historiantutkimuksen dilemma: riippuuko historian kulku yksittäisten persoonien vaikutuksesta vai ohjaavatko sitä kulloisetkin aatevirtaukset? Toinen kysymykseni on systemaatikon: millaista kulttuurista kuvaa teos pyrkii edistämään? Ensimmäiseen kysymykseen vastauksena todettava on, että yksilön ja yhteisön elämä on jatkuvaa menneisyyden kokemusten ja tulevaisuuden odotusten välistä dialogia. Kulttuurituotteet voivat käsitellä menneisyyttä, jonka osia ne eivät itse ole. Näin on esimerkiksi historiallisen dokumentin kohdalla. Historiallinen kerronta, tietoinen taaksepäin katsominen, voidaan rinnastaa historiankirjoitukseen kirjailija Jaan Krossin (1983) tavoin: "Historia esitetään mielikuvituksen vapaudella mutta kuviteltu saa lukijan tajunnassa tositapahtumien merkittävyyden." Romanihistoriakaan ei ole kiistaton, ja siitä voidaan fantasioida. Toisaalta teos avaa monin tavoin romanihistorian ja historiantutkimuksen näkökulmia ja käsitteitä. Asiasta tarkemmin kiinnostunut saa kirjallisuusluetteloiden kautta vinkkejä niistä teoksista ja lähteistä, joiden parissa aihepiiriin perehtymistä kannattaa jatkaa.

Kiintoisimmillaan Suomen romanien historia liikkuu kulttuurien rajamailla, oli sitten kyseessä rajanylitykset parisuhteessa (Tervonen), kielessä (Granqvist), uskonnossa (Hedman), pukeutumisessa ja tavoissa (Viljanen) tai vaikkapa musiikissa (Blomster). Romanitkaan eivät ole eläneet kulttuurisessa umpiossa vaan jatkuvassa vuorovaikutuksessa valtaväestöön nähden. Teos onkin varmasti tähän kenttään tervetullut, eikä ole vaikea ennustaa, että se kuluu sekä opiskelijoiden että tutkijoiden käsissä. Onhan niin, että historiallinen tutkimus antaa tarpeellista etäisyyttä oman aikamme arviointiin.

\section{KirjallisuUs}

KROSS, JAAN 1983: Historiallinen romaani Eestissä. - Parnasso 3.

Filosofian tohtori Kai Åberg toimii perinnemusiikintutkimuksen dosenttina ja tutkijana Itä-Suomen yliopistossa. 